\title{
Effect of Different Nutrient Management Practices on Yield Potential of Summer Cowpea [Vigna unguiculata L.] under South Gujarat Condition
}

\author{
Sejal Bhagariya*, K. A. Shah and K. M. Chaudhry \\ Department of Agronomy, Navsari, Agricultural University, \\ Eru Char Rasta, Navsari 396 450, Gujarat, India \\ *Corresponding author
}

\section{Keywords}

Cowpea, Yield, FYM, Nutrients managements, Economic

\section{Article Info}

Accepted:

24 August 2020

Available Online:

10 September 2020

\begin{abstract}
A B S T R A C T
A field experiment was conducted during summer season of 2019 at the college farm, Navsari Agricultural University, Navsari to study the "Effect of different nutrient management practices on yield potential of summer cowpea [Vigna unguiculata L.] under south Gujarat condition". The soil of the experimental field was clayey in texture having medium to poor drainage, low in available nitrogen and organic carbon, medium in available phosphorus and high in available potassium. Total eight treatments viz., Control $\left(\mathrm{T}_{1}\right)$, FYM 5 t/ha $\left(\mathrm{T}_{2}\right), 100 \%$ RDF (20:40:00:20 NPKS kg/ha) $\left(\mathrm{T}_{3}\right), \mathrm{FYM} 5$ t/ha $+50 \%$ RDF $\left(\mathrm{T}_{4}\right), \mathrm{FYM} 5 \mathrm{t} / \mathrm{ha}+100 \% \mathrm{RDF}\left(\mathrm{T}_{5}\right), \mathrm{FYM} 5 \mathrm{t} / \mathrm{ha}+50 \% \mathrm{RDF}+1 \%$ spray of EBPS at 30 DAS and 60 DAS $\left(\mathrm{T}_{6}\right)$, FYM 5 t/ha $+100 \% \mathrm{RDF}+1 \%$ spray of EBPS at 30 DAS and $60 \mathrm{DAS}\left(\mathrm{T}_{7}\right)$ and FYM 5 t/ha $+100 \% \mathrm{RDF}+1 \%$ spray of urea at $60 \mathrm{DAS}\left(\mathrm{T}_{8}\right)$ were tested in randomized block design with three replications. An application of FYM 5 t/ha + $100 \% \mathrm{RDF}+1 \%$ spray of EBPS at 30 DAS and 60 DAS recorded significantly higher plant height $(64.50 \mathrm{~cm})$ at harvest, number of branches per plant $(5.07)$, number of pods per plant (13.67), pod length (13.43), number of seeds per pod (11.67), seed yield (1744 $\mathrm{kg} / \mathrm{ha}$ ), haulm yield (4238 kg/ha) and harvest index (29.18\%) over control. Similarly, the maximum gross realization Rs 99932/ha and net realization of Rs 58957/ha with BCR value of 2.44 were also observed with the application of FYM 5 t/ha $+100 \%$ RDF $+1 \%$ spray of EBPS at 30 DAS and 60 DAS.
\end{abstract}

\section{Introduction}

Cowpea (Vigna unguiculata L. Walp) is one of the most important pulse crops native of Central Africa and belong to family Leguminoceae. Cowpea is called as vegetable meat due to high content of protein in grain (23.4\%), with better biological value on dry weight basis. It also contents highly nutritious constitution of fat $(1.8 \%)$ and carbohydrates
$(60.3 \%)$ as well as rich source of $\mathrm{Ca}$ and Fe. Apart from this, cowpea forms excellent forage, fodder as hay, green fodder and concentrates and it produces a heavy vegetative growth and covers the ground thereby, it checks the soil erosion. Cowpea known to improve soil fertility as they fix atmospheric nitrogen in soil at the rate of 80$85 \mathrm{~kg} /$ ha through symbiotic nitrogen fixation with the help of bacterium called Rhizobia. 
Thus cowpea plant is a mini-fertilizer factory itself. Due to their short duration, they can be grown as main crop, intercrop, catch crop, mulch crop and green manure crop.

Cowpea is a warm-season crop well adapted to many areas of the humid tropics and temperate zones. It is also called as black eye pea, black eye bean, southern pea, china pea, marble pea, chowli and lobiya. In India, it is cultivated in 654 lakh ha with an annual production of 599 lakh tonnes leading to average productivity of $916 \mathrm{~kg} / \mathrm{ha}$ (Anonymous, 2015). The area under cowpea cultivation in Gujarat is about 0.27 lakh hectares with an annual production of 2.89 lakh tonnes and the productivity of 1049 $\mathrm{kg} / \mathrm{ha}$ (Anonymous, 2012).

In India, frequency of pulses consumption is much higher than any other source of protein, which indicates the importance of pulses in their daily food habits. The domestic average production of pulses was around 18.1 million tonnes over the last three years. Pulses production in India has not kept up with growth in demand calling for import to the tune of 2.0 to 4.0 million tonnes (Raj et al., 2013). As per recommendation of WHO minimum requirement of pulses is 80 $\mathrm{g} /$ capita/day, but it is available less than 40 g/capita/day. Therefore, the production and productivity needs to improve to satisfied the demand of ever increasing population. Recently, integrated nutrient management has emerged as a sustainable practice which is able to boost up production, productivity and quality of the product, without causing any negative hazardous effect on crop and environment.

The combined use of organic and inorganic sources of plant nutrient not only improved the production and profitability of field crops, rather it helps in maintaining the permanent fertility status of soil (Dubey and Gupta,
1996; Kumar and Singh, 2010). Incorporation of FYM or organic manure alone or integration with chemical fertilizers improves not only the nutrient use efficiency, but also increases available nutrient status of soil with enhanced soil biological activity which in turn provides a congenial physical condition and improved availability of nutrient in the rhizosphere (Kanwar et al., 2017). Further, it helps in mineralization of nutrients in the rhizosphere improves crop growth and provides a better source-sink relationship by enhancing synthesis and allocation of metabolites to reproductive organs.

Foliar application is regarded as a preferred solution when quick supply of nutrients is hindered or the soil conditions are not conductive for the absorption of nutrients (Salisbury and Ross, 1985). Foliar spray technique helps the nutrients to reach the site of food synthesis directly, leading to no wastage and quick supply of food and thereby reduce the requirement of fertilizers. Moreover, foliage feeding practices would be more useful in early maturing crop, which could be combined with regular plant protection programmes. If foliar nutrition is applied it reduces the cost of cultivation which in turn reduces the amount of fertilizers thereby reduce the loss and also economizing crop production. Foliar application of urea at $50 \%$ flowering increased the yield and seed protein. In legumes, leaf senescence starts earlier before completion of maturity which break the source to sink relation, thereby reduce the yield. Nitrogen spray has been found to delay leaf senescence and improve yield (Palta et al., 2005).

Cultivation of cowpea in summer season is increasing in Gujarat, especially in south Gujarat. Considering the above facts and very less work done in south Gujarat region the experiment has been planned to study the "Effect of different nutrient management 
practices on yield potential of summer cowpea [Vigna unguiculata L.] under south Gujarat condition" during summer season of 2019.

\section{Materials and Methods}

A field experiment was conducted in summer season of 2019 at the college farm, Navsari Agricultural University, Navsari, Gujarat. The soil of the experimental field was clayey in texture having medium to poor drainage, soil $\mathrm{pH} 8.08$, EC $0.50 \mathrm{ds} / \mathrm{m}$ and organic carbon content $0.40 \%$. The soil is low in available nitrogen $(213.87 \mathrm{~kg} / \mathrm{ha})$, medium in available phosphorus (47.27 $\mathrm{kg} / \mathrm{ha})$ and high in available potassium (312.10 $\mathrm{kg} / \mathrm{ha})$ were determined by Kjeldahl's method, Olsen's method and Flame photometric method, respectively. Total eight treatments viz., Control $\left(\mathrm{T}_{1}\right)$, FYM 5 t/ha $\left(\mathrm{T}_{2}\right), 100 \% \mathrm{RDF}$ (20:40:00:20 NPKS kg/ha) ( T $\left._{3}\right)$, FYM 5 t/ha $+50 \%$ RDF $\left(\mathrm{T}_{4}\right)$, FYM 5 t/ha $+100 \%$ RDF $\left(\mathrm{T}_{5}\right), \mathrm{FYM} 5 \mathrm{t} / \mathrm{ha}+50 \% \mathrm{RDF}+1 \%$ spray of EBPS at 30 DAS and 60 DAS (T 6 ), FYM 5 t/ha $+100 \% \mathrm{RDF}+1 \%$ spray of EBPS at 30 DAS and 60 DAS $\left(\mathrm{T}_{7}\right)$ and FYM 5 t/ha +100 $\% \mathrm{RDF}+1 \%$ spray of urea at $60 \mathrm{DAS}\left(\mathrm{T}_{8}\right)$ were tested in randomized block design with three replications. Cowpea variety "GC-4" seeds were sown at $45 \times 15 \mathrm{~cm}$ spacing. Farm yard manure was incorporated about 15 days before sowing in soil as per treatments. The entire dose of fertilizer was applied as per the treatments at basal application just before sowing and spraying of enriched banana pseudostem sap and urea were applied as per the treatments. Enriched banana pseudostem sap is first time prepared and patented by Navsari Agricultural University, Navsari which was developed by team of National Innovative Project on "A Value Chain on Utilization of Banana Pseudostem for Fiber and Other Value Added products." This enriched sap is a very good source of essential plant nutrients namely N (70.0 mg/l), P (26.1 $\mathrm{mg} / \mathrm{l}), \mathrm{K}(170 \mathrm{mg} / \mathrm{l}), \mathrm{Fe}$ (7.44 mg/l), Mn (2.66 $\mathrm{mg} / \mathrm{l}), \mathrm{Zn}(0.40 \mathrm{mg} / \mathrm{l}), \mathrm{Cu}(0.26 \mathrm{mg} / \mathrm{l})$ etc. as well as hormones $\mathrm{GA}_{3}$ and cytokinin. Urea, DAP and gypsum were taken as fertilizer sources for N, P and S, respectively. All other operation was performed as per recommendations of the crops. The data on seed and haulm yields as well as protein content were recorded under various treatments after harvest of crop. The results were analysis statistically to draw suitable interference as per the standard ANOVA techniques suggested by Gomez and Gomez (1984).

\section{Results and Discussion}

\section{Growth attributes}

The variations in growth attributes of cowpea due to different nutrient management treatments were found to be significant. Significantly the taller plant height at harvest $(64.50 \mathrm{~cm})$ were registered with the application of $\mathrm{T}_{7}$ (FYM 5 t/ha $+100 \% \mathrm{RDF}$ $+1 \%$ spray of EBPS at 30 and 60 DAS) over control, which was at par with with rest of the treatments, except under the application of FYM 5 t/ha. The lowest plant heights at harvest $(51.13 \mathrm{~cm})$ were recorded under control. The percentage increase in the plant height at harvest of 26.15, 23.61 and 22.43 per cent under the treatment $\mathrm{T}_{7}, \mathrm{~T}_{5}$ and $\mathrm{T}_{8}$ over control, respectively. Increased in plant height under the different nutrient management practices might be due to two reason, firstly addition of FYM along with in organic fertilizers in to soil improved physical, chemical and biological properties of soil and this leads to improve the root growth and development and thereby uptake of nutrients and water from greater soil volume resulting in to better plant growth and secondly foliar application of nutrients including the micronutrient at a critical crop growth stage helps in regulating the cell 
division and multiplication as well as cell elongation and development of leaves and other plant's part. It also helps in enhance the synthesis of carbohydrates and protein in plants and ultimately the photosynthetic activity resulting in better development of plant growth. Similar type of results are finding by Devi et al., (2013), Tahir et al., (2014), Patel et al., (2015), Singhal et al., (2015), Chauhan et al., (2016), Prajapati et al., (2016), Pargi et al., (2018), Rajemahadik et al., (2018) and Verma et al., (2018) with respect to plant height.

An application of FYM 5 t/ha + $100 \%$ RDF + $1 \%$ spray of EBPS at 30 and 60 DAS $\left(T_{7}\right)$ produced significantly higher number of branches per plant (5.07) over control, which was remain at par with rest of the treatments, except under the treatment of FYM 5 t/ha (4.33). This could be attributed due to favourable effect of foliar spray of nutrients and combined application of organic and inorganic fertilizers added in to the soil helps in improvement of physico-chemical properties of soil and assures the quick and easy availability of essential plant nutrients resulted in better crop growth in terms of number of branches per plant. Positive responses in terms of growth attributes reported by Chaudhary and Yadav (2011), Jat et al., (2012), Tahir et al., (2014), Patel et al., (2015), Chauhan et al., (2016), Prajapati et al., (2016), Gohil et al., (2017), Pargi et al., (2018) and Verma et al., (2018).

\section{Yield attributes}

All most all the yield attributing parameters (Table-1) viz., numbers of pods per plant, pod length and number of seeds per pod were remarkably influenced by different nutrient management treatments. An application of FYM 5 t/ha $+100 \%$ RDF $+1 \%$ spray of EBPS at 30 and 60 DAS $\left(\mathrm{T}_{7}\right)$ was observed remarkably the highest number of pods per plant and pod length, but it were remain at par with remaining all other treatments, except the control and FYM 5 t/ha. Significantly lowest pods per plant (9.67) and pod length $(11.27 \mathrm{~cm})$ were registered with control. Number of seed per pod (11.67) was recorded significantly higher due to application of FYM $5 \mathrm{t} / \mathrm{ha}+100$ $\% \mathrm{RDF}+1 \%$ spray of EBPS at 30 and 60 DAS $\left(\mathrm{T}_{7}\right)$ over control, but it was statistically at par with application of FYM 5 t/ha $+100 \%$ RDF + $1 \%$ spray of urea at 60 DAS (11.33) and FYM $5 \mathrm{t} / \mathrm{ha}+50 \% \mathrm{RDF}+1 \%$ spray of EBPS at 30 and 60 DAS (11.13). Treatment $\mathrm{T}_{7}, \mathrm{~T}_{8}$ and $\mathrm{T}_{6}$ increases the 41.37, 37.23 and $30.29,19.17$, 18.01 and 15.35 as well as $24.15,20.53$ and 18.40 per cent higher number of pods per plant, pod length and number of seeds per pod over control, respectively. Test weight of cowpea did not influenced significantly by different nutrient management treatments. However, the numerically higher value of test weight (13.70 g) was observed under the same treatment of FYM 5 t/ha $+100 \%$ RDF $+1 \%$ spray of EBPS at 30 and $60 \mathrm{DAS}\left(\mathrm{T}_{7}\right)$ followed by $13.53 \mathrm{~g}$ in treatment $\mathrm{T}_{3}$. Increasing in the yield attributes may be due to the fact that farmyard manure increases the adsorptive power of soil for cation and anion and these absorbed ions are released slowly for the entire crop growth period resulted in better nutrient availability at active crop growth. Secondly, integrated use of organic, inorganic and foliar spray of nutrients at a critical crop growth stages resulted in better growth of plants associated with increased availability of nutrients might have resulted in greater translocation of photosynthates from source to sink site that favourably influenced flowering, fruiting and ultimately resulted into increased number of pods per plant, pod length and number of seeds per pod. These findings are substantiated with those reported by Chaudhary and Yadav (2011), Devi et al., (2013), Singhal et al., (2015), Prajapati et al., (2016), Gohil et al., (2017), Singh et al., (2017) and Verma et al., (2018). 
Table.1 Effect of different nutrient management practices on growth and yield attributes of summer cowpea

\begin{tabular}{|c|c|c|c|c|c|c|}
\hline Treatment & $\begin{array}{c}\text { Plant height at } \\
\text { harvest }(\mathrm{cm})\end{array}$ & $\begin{array}{c}\text { Number of } \\
\text { branches per } \\
\text { plant }\end{array}$ & $\begin{array}{l}\text { No. of } \\
\text { pods/ } \\
\text { plant }\end{array}$ & $\begin{array}{l}\text { Pod } \\
\text { length } \\
(\mathrm{cm})\end{array}$ & $\begin{array}{l}\text { No of seeds } \\
\text { per pods }\end{array}$ & $\begin{array}{c}\text { Test } \\
\text { weight }(\mathrm{g})\end{array}$ \\
\hline $\mathbf{T}_{1:}$ Control & 51.13 & 3.80 & 9.67 & 11.27 & 9.40 & 12.63 \\
\hline$T_{2:}$ FYM 5 t/ha & 54.00 & 4.33 & 10.13 & 11.53 & 10.00 & 13.33 \\
\hline $\begin{array}{c}\text { T }_{3}: 100 \% \text { RDF (20:40:00:20 } \\
\text { NPKS kg/ha) }\end{array}$ & 61.83 & 4.87 & 11.67 & 12.40 & 10.33 & 13.53 \\
\hline $\mathrm{T}_{4}:$ FYM 5 t/ha $+50 \%$ RDF & 59.93 & 4.60 & 11.47 & 12.30 & 10.47 & 13.43 \\
\hline $\mathrm{T}_{5:}$ FYM $5 \mathrm{t} / \mathrm{ha}+100 \%$ RDF & 63.20 & 4.73 & 12.07 & 12.90 & 10.40 & 13.47 \\
\hline $\begin{array}{l}\mathrm{T}_{6}: \mathrm{FYM} 5 \mathrm{t} / \mathrm{ha}+50 \% \mathrm{RDF}+1 \% \\
\text { spray of EBPS at } 30 \text { and } 60 \text { DAS }\end{array}$ & 62.17 & 4.93 & 12.60 & 13.00 & 11.13 & 13.47 \\
\hline $\begin{array}{l}\mathrm{T}_{7}: \mathrm{FYM} 5 \mathrm{t} / \mathrm{ha}+100 \% \mathrm{RDF}+1 \% \\
\text { spray of EBPS at } 30 \text { and } 60 \mathrm{DAS}\end{array}$ & 64.50 & 5.07 & 13.67 & 13.43 & 11.67 & 13.70 \\
\hline $\begin{array}{l}\mathrm{T}_{8}: \text { FYM } 5 \mathrm{t} / \mathrm{ha}+100 \% \mathrm{RDF}+1 \% \\
\text { spray of urea at } 60 \mathrm{DAS}\end{array}$ & 62.60 & 4.80 & 13.27 & 13.30 & 11.33 & 13.20 \\
\hline SEm \pm & 2.62 & 0.24 & 0.82 & 0.47 & 0.39 & 0.61 \\
\hline $\mathrm{CD}(\mathrm{P}=\mathbf{0 . 0 5})$ & 8.03 & 0.72 & 2.50 & 1.44 & 1.18 & NS \\
\hline CV \% & 7.58 & 8.86 & 11.99 & 6.48 & 6.32 & 7.91 \\
\hline
\end{tabular}


Table.2 Effect of different nutrient management practices on yield and economics of summer cowpea

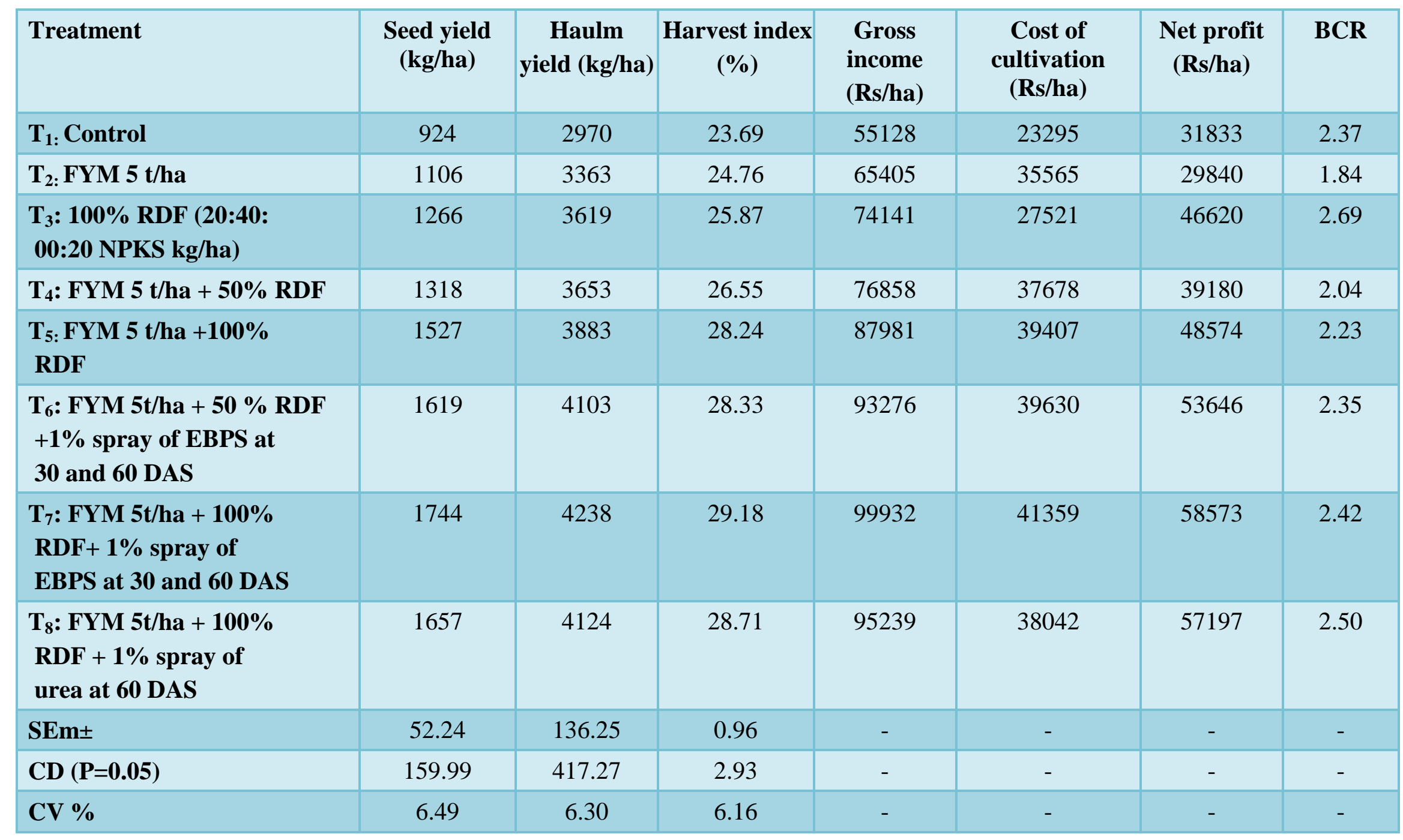




\section{Seed and haulm yield}

The different nutrient management treatments showed significant difference on seed and haulm yields of cowpea (Table-2). Significantly higher seed yield $(1744 \mathrm{~kg} / \mathrm{ha})$ of cowpea was produced with application of FYM 5 t/ha $+100 \%$ RDF $+1 \%$ spray of EBPS at 30 and 60 DAS $\left(T_{7}\right)$ over control, but it was statistically at par with application of FYM 5 t/ha $+100 \%$ RDF $+1 \%$ spray of urea at $60 \mathrm{DAS}(1657 \mathrm{~kg} / \mathrm{ha})$ and FYM $5 \mathrm{t} / \mathrm{ha}$ $+50 \% \mathrm{RDF}+1 \%$ spray of EBPS at 30 and 60 DAS $(1619 \mathrm{~kg} / \mathrm{ha})$. The haulm yield (4238 $\mathrm{kg} / \mathrm{ha}$ ) was observed remarkably higher with application of FYM 5 t/ha + $100 \%$ RDF + 1 $\%$ spray of EBPS at 30 and $60 \mathrm{DAS}\left(\mathrm{T}_{7}\right)$ over rest of the treatments except, the application of FYM 5 t/ha $+100 \%$ RDF $+1 \%$ spray of urea at 60 DAS (4124 kg/ha), FYM 5 t/ha + $50 \% \mathrm{RDF}+1 \%$ spray of EBPS at 30 and 60 DAS (4103 kg/ha) and FYM 5 t/ha $+100 \%$ RDF (3883 kg/ha). The remarkable lowest seed yield (924 kg/ha) and haulm yield (2970 $\mathrm{kg} / \mathrm{ha}$ ) of cowpea were obtained under control. There were 88.74, 79.33 and 75.22 per cent seed yield and 42.69, 38.86 and 38.17 per cent haulm yield increased under the treatment $T_{7}, T_{8}$ and $T_{6}$ over the control, respectively. The increase in seed yield with application of different nutrient management treatments was mainly due to cumulative effect of significant increased in the growth and yield attributing component like number of branches, number of pods per plant, pod length and number of seeds per pod. Similarly, the haulm yield was remarkably increased due to the significant improvement in the growth attributing characters viz., plant height and number of branches per plant. The overall improvement in all the growth and yield attributing components may be due to synergistic effect of combined use of organic and inorganic manures as well as foliar spray at critical crop growth stage. These results are in line with those published by Chaudhary and Yadav (2011), Devi et al., (2013), Shukla et al., (2013), Meena et al., (2014), Das and Jana (2015), Patel et al., (2015), Dhakal et al., (2016), Prajapati et al., (2016), Joshi et al., (2018) and Shroti et al., (2018).

Harvest index (Table-2) of cowpea significantly influenced by different nutrient management treatments. The harvest index $(29.18 \%)$ was observed remarkably higher with application of FYM 5 t/ha $+100 \%$ RDF $+1 \%$ spray of EBPS at 30 and 60 DAS $\left(\mathrm{T}_{7}\right)$, which remain at par with application of FYM $5 \mathrm{t} / \mathrm{ha}+100 \% \mathrm{RDF}+1 \%$ spray of urea at 60 DAS (28.71\%), FYM 5 t/ha $+50 \%$ RDF +1 $\%$ spray of EBPS at 30 and 60 DAS (28.33 $\%)$, FYM 5 t/ha + $100 \%$ RDF (28.24 \%) and FYM 5 t/ha $+50 \%$ RDF $(26.55 \%)$. The remarkably lower harvest index of $23.69 \%$ was recorded under control. These results corroborated the findings of Chaudhary and Yadav (2011), Shukla et al., (2013), Patel et al., (2015), Dhakal et al., (2016) and Gohil et al., (2017).

\section{Economics}

The data presented in Table 2 revealed that the application of FYM $5 \mathrm{t} / \mathrm{ha}+100 \% \mathrm{RDF}+$ $1 \%$ spray of EBPS at 30 and 60 DAS incurred maximum gross realization (99932 Rs./ha) and net realization (58957 Rs./ha) with BCR (2.44), which was closely followed by the treatment FYM 5 t/ha $+100 \%$ RDF + $1 \%$ spray of urea at 60 DAS record gross realization of 95239 Rs./ha, net realization 55852 Rs./ha and B: C ratio of 2.42 . Whereas, the highest B: C ratio of 2.69 was recorded with the $100 \%$ RDF (20:40:00:20 $\mathrm{kg}$ NPKS/ha). The higher gross and net returns found under the combination of inorganic and organic fertilizers with the foliar spray of nutrients might be due to higher seed yield obtained as compared to cost involved under this treatment. The lowest gross realization of Rs. 55128/ha was obtained under the control 
treatment, where as lowest net realization of Rs. 30224/ha and BCR of 1.86 was obtained under the treatment FYM 5 t/ha. It might be due to lower yield under control and high cost of FYM. The increases in the net return with the integration of $5 \mathrm{t} \mathrm{FYM/ha} \mathrm{with} 100 \%$ RDF along with foliar spay of $1 \%$ EBPS at 30 and 60 DAS over control, FYM 5 t/ha and $100 \%$ RDF were 46.0, 48.73 and 20.93 per cent, respectively. Similar views in direction of present finding were also expressed by Kuttimani and Velayutham (2011), Jat et al., (2012), Devi et al., (2013) and Verma et al., (2018).

In conclusion from the one year experimental results, it can be proved that an application of FYM 5 t/ha + 50\% RDF (10:20:00:10 kg $\mathrm{NPKS} / \mathrm{ha})+1 \%$ spray of EBSP at 30 and 60 DAS improved the plant height, number of branches per plant, number of pods per plant, pod length, number of seeds per pod, seed and haulm yield and maximum net return. Integrated use of organic, inorganic and foliar spray of enrich banana pseudostem sap may be suggested for the higher yield and will be useful to enhance the productivity of summer cowpea.

\section{References}

Anonymous 2012. Ministry of Agriculture and Farmers Welfare, Government of India.

Anonymous 2015. Ministry of Agriculture and Farmers Welfare, Government of India.

Chaudhary, G. L. and Yadav, L. R. 2011. Effect of fertility levels and foliar nutrition on cowpea productivity. Journal of Food Legumes, 24(1): 67-68.

Chauhan, J., Paithankar, D. H., Khichi, P., Ramteke, V., Srinivas, J. and Baghel, M. M. 2016. Studies on integrated nutrient management in cowpea. Research Journal of Agricultural
Science, 7(2): 256-259.

Das, S. K. and Jana, K. 2015. Effect of foliar spray of water soluble fertilizer at pre flowering stage on yield of pulses. Agricultural Science Digest, 35(4): 275 279.

Devi, K. N., Singh, T. B., Athokpam, H. S. and Brajendra, N. 2013. Influence of inorganic, biological and organic manures on nodulation and yield of soybean (Glycine max Merril L.) and soil properties. Australian Journal of Crop Science, 7(9): 1407-1415.

Dhakal, Y., Meena, R. S. and Kumar, S. 2016. Effect of INM on nodulation, yield, and quality and avilable nutrient status in soil after harvest of green gram. Legume Research, 39(4): 590-594.

Dubey, S. K. and Gupta, P. K. 1996. Bioorganic fertilizers for improving productivity of legumes in vertisols of M.P. Fertilizer News. 41(8): 33-39.

Gohil, K. O., Kumar, S. and Jat, A. L. 2017. Effect of plant geometry, seed priming and nutrient management on growth, yield and economics of summer greengram [Vigna radiata (L.) Wilczek]. International Journal of Current Microbiology and Applied Sciences, 6(9): 2386-2390.

Gomez, K. A. and Gomez, A. A. 1984. Statistical Methods for Agricultural Research. John Wiley and Sons, New York, pp. 139-264.

Jat, S. L., Prasad, K. and Parihar, C. M. 2012. Effect of organic manuring on productivity and economics of summer mungbean (Vigna radiata var. radiata). Annals of Agricultural Research, 33(1 \& 2): 17-20.

Joshi, J. R., Patel, V. M., Basrad, H. L., Macwan, S. M. and Ehsas, J. 2018. Effect of land configuration and fertilizer management practices on growth, yield and yield attributes and economics of summer cowpea (Vigna 
unguiculata L.) under south Gujarat condition. International Journal of Current Microbiology and Applied Sciences, 7(1): 1148-1155.

Kanwar, A, Sharma, S. R., Yadav, K. R and Yadav, G. L. 2017. Effect of organic and inorganic nutrition on fertility status of soil and yield of vegetable cowpea. Chemical Science Review and Letters, 6(23), 1510-1514.

Kumar, V. and Singh, S. Y. 2010. Integrated nutrient management an ideal approach for enhancing agricultural production and productivity. Indian Journal of Fertilizers, 1(6): 41-53.

Kuttimani, R. and Velayutham, A. 2011. Foliar application of nutrients and growth regulators on yield and economics of greengram. Madras Agricultural Journal, 98(4-6): 141-143.

Meena, J. S., Verma, H. P. and Pincholi, P. 2014. Effect of fertility levels and biofertilizers on yield, quality and economic of cowpea. Agriculture for Sustainable Development, 2(2): 162164.

Palta, J. A., Nandwal, A. S., Kumari, S. and Turner, N. C. 2005. Foliar nitrogen application increase the seed yield and protein content in chickpea (Cicer arietinum L.) subject to terminal drought. Australian Journal of Agricultural Research, 56: 105-112.

Pargi, K. L., Leva, R. L., Vaghasiya, H. Y. and Patel, H. A. 2018. Integrated nutrient management in summer cowpea (Vigna unguiculata L.) under south Gujarat condition. International Journal of Current Microbiology and Applied Sciences, 7(9): 1513-1522.

Patel, A. D., Patel, D. D., Patel, T. U. and Prajapati, D. R. 2015. Effect of integrated nutrient management on growth parameters, yield attributes and yield of summer greengram (Vigna radiata L.) under south Gujarat condition. AGRES- An international eJournal, 4(1), 72-78.

Prajapati, S. K., Tyagi, P. K., Chourasia, S. K. and Upadhyay, A. K. 2016. Effect of integrated nutrient management practices on growth and yield of summer mungbean (Vigna radiata $\mathrm{L}$.). A Journal of Multidisciplinary Advance Research, 5(1), 102-107.

Raj, A. D., Yadav, V. and Rathod, J. H. 2013. Impact of front line demonstration (FLD) on the yield of pulses. International Journal of Scientific and Research Publication, 3(9): 2250-3153.

Rajemahadik, V. A., Shetye, V. N., Chavan, V. G., Chavan, S. A. and Mahadkar, U. V. 2018. Irrigation and fertilizer management in cowpea under zero tilled condition of south konkan coastal zone of Maharashtra, India. International Journal of Current Microbiology and Applied Science, 7(12): 2713-2724.

Salisbury, F. B. and Ross, C. W. 1985. Plant physiology. $3^{\text {rd }}$ edition, Wadsworth Publicing Company, Belmont, CA., pp:540.

Shroti, S. K., Pathak, A., Tiwari, A., Gupta, A. and Chauhan, S. K. 2018. Morphological, physiological and yield analysis of black gram under different levels of FYM, PSB and phosphorus. International Journal of chemical Studies, 6(3): 403-411.

Shukla, M, Patel, R. H., Verma, R., Deewan, $P$ and Dotaniya, M. L. 2013. Effect of bio-organics and chemical fertilizers on growth and yield of chickpea (Cicer arietinum L.) under middle Gujarat conditions. Society for Plant Research, 26(1), 183-187.

Singh, V., Singh, A. K., Singh, M. K., Raghuvanshi, T. and Singh, U. 2017. Morphological of yield traits of cowpea (Vigna unguiculata L. Walp.) under integrated nutrient management. International Journal of Current 
Microbiology and Applied Sciences, 6(10): 3402-3407.

Singhal, V. K., Patel, G. G., Patel, D. H., Kumar, U. and Saini, L. K. 2015. Effect of foliar application of water soluble fertilizers on growth, yield and economics of vegetable cowpea production. The Ecoscan, 7: 79-83.

Tahir, M., Maqbool, R., Majeed, A., Rehman, A., and Zafar, M.A. 2014. Potential of foliar applied diammonium phosphate and potassium in achieving maximum productivity and quality of mash bean. Scientia Agriculturae, 7(3): 147-149.

Verma, H., Parihar, M. S., Nawange, D. D. and Sahu, M. K. 2018. Effect of integrated nutrient management on growth and yield of cowpea (Vigna unguiculata L. Walp). International Journal of Agriculture Sciences, 10(18): 7186-7188.

\section{How to cite this article:}

Sejal Bhagariya, K. A. Shah and Chaudhry, K. M. 2020. Effect of Different Nutrient Management Practices on Yield Potential of Summer Cowpea [Vigna unguiculata L.] under South Gujarat Condition. Int.J.Curr.Microbiol.App.Sci. 9(09): 3267-3276.

doi: https://doi.org/10.20546/ijcmas.2020.909.405 